\title{
Bioactivity and genetic screening of marine actinobacteria associated with red algae Gelidiella acerosa
}

\author{
Maria Ulfah ${ }^{1}$, Noer Kasanah ${ }^{2, *}$, and Niken Satuti Nur Handayani ${ }^{1}$ \\ ${ }^{1}$ Faculty of Biology, Universitas Gadjah Mada, Jl. Teknika Selatan, Sekip Utara, Sinduadi, Mlati, Sleman, Daerah Istimewa Yogyakarta 55281, \\ Indonesia \\ ${ }^{2}$ Department of Fisheries, Faculty of Agriculture, Universitas Gadjah Mada, Bulaksumur, Caturtunggal, Depok, Sleman, Daerah Istimewa \\ Yogyakarta 55281 Indonesia \\ *Corresponding author: noer.kasanah@ugm.ac.id
}

\begin{abstract}
Bacterial resistance to existing antibiotics has driven a search for new antibiotics from marine actinobacteria. Bioactivity and genetic screening of actinobacteria associated with red algae Gelidiella acerosa were conducted to discover new antibacterial compounds against Vibrio alginolyticus. A total of 14 actinobacteria isolates were obtained from G. acerosa. The isolates were subjected to genetic screening for nrps (non-ribosomal peptide synthetase) and FADH ${ }_{2}$-dependent halogenase genes. The isolates' ability to produce secondary metabolites was examined by fermentation in various media in a six-well mini plate. The bioactivity of the secondary metabolites was screened using a microtiter assay and the agar overlay method. The results showed that all 14 isolates had the nrps gene, whereas none had the halogenase gene. Meanwhile, eight of the actinobacteria isolates showed antibacterial activity against V. alginolyticus.
\end{abstract}

KEYWORDS actinobacteria; antibiotic; $\mathrm{FADH}_{2}$-dependent halogenase; NRPS; red algae

\section{Introduction}

Antibiotics play a crucial role in treating bacterial infections in both humans and animals. Overuse and inappropriate prescribing of antibiotics contribute to problems antibiotic resistance and emergence of new pathogenic bacteria (Luyt et al. 2014). One of the pathogenic bacteria in marine aquaculture and human disease is Vibrio sp. (Austin 2010). Vibrio spp. are commonly present in seawater, sediments and occupy aquatic environments at temperatures ranging from 10 to $30^{\circ} \mathrm{C}$ and contaminate seafood. Available antibiotic was limited to combat the infection in human (Shaw et al. 2014). New antibiotics is necessary for those cases and due to limited shelf-life of antibiotics (Kasanah and Hamann 2004). In this study Vibrio alginolyticus was used as test strain because $V$. alginolyticus has high potential as reservoirs of disease-carrying genes in other Vibrio sp. and cause gastroenteritis and peritonitis due to consumption of seafood contaminated by these bacteria (Gómez-León et al. 2005; Mustapha et al. 2013).

The Marine environment is a complex and unique ecosystem characterized by high salinity and pressure, low temperatures and variable oxygen concentrations (Bull et al. 2000). A marine ecosystem consists of huge variety forms of life that allow interactions and associations between themselves. The most frequent associations are between eukaryotic cells and microorganisms (Egan et al. 2008). Many bioactive compounds such as antibiotics, antitumor, antifouling or antioxidant from the marine microorganism are due to the involvement of specific function in their respective hosts (El-Shatoury et al. 2009).

Red algae, the most potential sources of unique secondary metabolites compared with green and brown algae (Schwartsmann et al. 2001). More than 1400 secondary metabolites were successfully isolated from red algae from 1963-2016 (Blunt et al. 2014). Red algae live as host for diverse and abundant symbiotic microorganisms. These bacteria protect the host from a predator or others harmful things in pelagic areas (Singh and Reddy 2014) and produce important compounds for human and animal health (Kanagasabhapathy et al. 2006; Penesyan et al. 2010). Various novel compounds with biological activity have already been identified from seaweedassociated bacteria. Streptomyces sp. YM5-799 associated brown algae Analipus japonicus produced Streptobactin as an iron chelating activity for treatment human disease (Matsuo et al. 2011). Bacterial strain member of the genus Alteromonas was associated with the red algae Laurencia pacifica produced a high molecular weight of polysaccharide and used for industrial application (SoriaMercado et al. 2012). Gelidiella acerosa is a potential source of bioactive compounds. The research about sec- 
ondary metabolites of associated microorganism of Gelidiella acerosa was unexplored. Some studies have demonstrated the presence of antibacterial activity from Gelidiella acerosa but not the associated microorganism. A study reported that ethanol extract of Gelidiella acerosa has antibacterial activity against Staphylococcus aureus (Elsie et al. 2011).

Marine bacteria as associated microorganisms are possible to participate in the biosynthesis of bioactive compound. The use of microorganism is more effective as a source of bioactive compound than its host due to the short life cycle of actinobacteria and the ability to be cultured in vitro (Piel et al. 2004). Approximately $80 \%$ of antibiotics have been found mainly produced by actinobacteria especially genus Streptomyces and Micromonospora (Naikpatil and Rathod 2011). Actinobateria continue to play a significant role in drug discovery and development. Bioactive compounds produced by marine actinobacteria were abysomicin $\mathrm{C}$, diazepinomicin, and salinoporamide A (Lam 2006). Because of the excellent record of actinobacteria, a significant effort has been focused on the isolation of novel actinobacteria from marine for developing drug discovery especially antibiotics.

A new strategy for selecting potential actinobacteria is through genetic approach by detecting gene target involved in the biosynthesis of bioactive compounds. These bioactive compounds can be the result of the activity of non-ribosomal peptide synthetases (NRPS) and $\mathrm{FADH}_{2}-$ dependent halogenase. NRPS is multimodular enzyme consist of three domains, A domain (Adenylation domain) serves as an introduction and activation substrate, domain PCP (Peptidyl Carrier Protein) for transfer to the center catalyst and the $\mathrm{C}$ domain (Condensation domain) is connecting peptide bonds to form the final product (Schwarzer and Marahiel 2001). FADH 2 -dependent halogenase as tailoring enzyme catalyzes genes encoding halogenated compounds, this gene is also part of the domain of NRPS gene cluster decisive one functional group of compound and determine the bioactivity (Hur et al. 2012). These gene encode a successful formation of antibiotics compounds such as chloramphenicol, vancomycin, and teicoplanin (Pée and Zehner 2003). Therefore, the objective of this study was to select the potential actinobacteria associated red algae Gelidiella acerosa through genetic screening of nrps and hal genes, and to examine antibacterial activity against $V$. alginolyticus.

\section{Materials and methods}

\subsection{Algae collection and preparation}

Red algae was collected from Drini Gunungkidul Yogyakarta Indonesia on 26th January 2015. Sample was identified as Gelidiella acerosa. Sample was rinsed with sterile fresh water, transferred in a sterile zip-lock bag and transported to the laboratory. One g of Gelidiella acerosa sample was aseptically cut into small pieces and placed in a sterile mortar with $1 \mathrm{~mL}$ of sterile water. Decimal dilutions were made up to 10-3 and plated on different isolation media.

\subsection{Isolation of actinobacteria from Gelidiella acerosa}

In order to obtain diversity of actinobacteria, five different media were used for the isolation: Actinobacteria Isolation Agar (Difco ${ }^{\mathrm{TM}}$ ), SC-SW, nutrient agar (Merck), WATSW, and marine agar (Scharlau). The composition of SCSW media were: $1 \%$ soluble starch; $0.003 \%$ casein; $0.2 \%$ $\mathrm{KNO}_{3} ; 0.2 \% \mathrm{NaCl} ; 0.002 \% \mathrm{CaCO}_{3} ; 0.005 \mathrm{MgSO}_{4} .7 \mathrm{H}_{2} \mathrm{O}$; $0.001 \% \mathrm{FeSO}_{4} .7 \mathrm{H}_{2} \mathrm{O} ; 1.8 \%$ agar in $60: 40$ sterile (seawater:distilled water) (Lee and Lee 2008). The composition of WAT-SW media were: $0.05 \% \mathrm{MgSO}_{4} .7 \mathrm{H}_{2} \mathrm{O} ; 0.05 \%$ $\mathrm{CaCl}_{2} .2 \mathrm{H}_{2} \mathrm{O} ; 1.5 \%$ bacto agar in $60: 40$ sterile (seawater:distilled water) (Lee 2006). The plate then incubated at room temperature for 7 days or more. All media were prepared using sterile seawater. After sterilized $25 \mathrm{ug} / \mathrm{mL}$ ketoconazole and $25 \mathrm{ug} / \mathrm{mL}$ cyprofloxacin were added in order to eliminate fungal contamination and fast growing bacteria.

\subsection{5 rRNA gene amplification}

Actinobacteria genome was extracted based on DNA extraction kit protocol (Wizard ${ }^{\circledR}$ DNA Purification Kit, Promega). PCR amplification of the 16S rRNA gene of the actinobacteria was performed based on Stach et al. (2003) using two specific primers: ActF (5'-CGCGGCCTATCAGCTTGTTG-3') and ActR (5'CCGTACTCCCCAGGCGGGG-3'). The final volume of reaction mixture of $25 \mu \mathrm{L}$ contained $12.5 \mu \mathrm{L}$ GoTaq ${ }^{\circledR}$ Green Master Mix, $1 \mu \mathrm{L}$ Primer 243F (0.4 mM), $1 \mu \mathrm{L}$ Primer 1378R (0.4 mM), $1 \mu \mathrm{L}$ DNA Template, $1 \mu \mathrm{L}$ sterile DMSO, and $8.5 \mu \mathrm{L}$ Nuclease Free-Water. The PCR program used was pre-denaturation $\left(95^{\circ} \mathrm{C}\right.$ for $\left.7 \mathrm{~min}\right), 30$ cycles of denaturation $\left(95^{\circ} \mathrm{C}\right.$ for $\left.45 \mathrm{~s}\right)$, annealing $\left(59^{\circ} \mathrm{C}\right.$ for $45 \mathrm{~s}$ ) and extension $\left(72^{\circ} \mathrm{C}\right.$ for $\left.60 \mathrm{~s}\right)$, and a final extension ( $72^{\circ} \mathrm{C}$ for $5 \mathrm{~min}$ ). The PCR process stopped at $4^{\circ} \mathrm{C}$.

\subsection{Screening of Non-Ribosomal Peptide Synthase (NRPS) gene}

Amplification of NRPS gene was performed using primers A3F (5'-GCSTACSYSATSTACACSTCSGG-3') and primer reverse A7R (5'-SASGTCVCC-SGTSCGGTAS3'). The final volume of reaction mixture of $25 \mu \mathrm{L}$ contained $12.5 \mu \mathrm{L}$ GoTaq ${ }^{\circledR}$ Green Master Mix, $1 \mu \mathrm{L}$ primer A3F $(0.4 \mathrm{mM}), 1 \mu \mathrm{L}$ primer A7R $(0.4 \mathrm{mM}), 1 \mu \mathrm{L}$ DNA Template, $1 \mu \mathrm{L}$ sterile DMSO, and $8.5 \mu \mathrm{L}$ Nuclease Free-Water. The PCR program used was pre-denaturation $\left(95^{\circ} \mathrm{C}\right.$ for $\left.3 \mathrm{~min}\right), 30$ cycles of denaturation $\left(95^{\circ} \mathrm{C}\right.$ for 30 s), annealing $\left(59^{\circ} \mathrm{C}\right.$ for $\left.30 \mathrm{~s}\right)$ and extension $\left(72^{\circ} \mathrm{C}\right.$ for 1 $\mathrm{min})$, and a final extension $\left(72^{\circ} \mathrm{C}\right.$ for $\left.7 \mathrm{~min}\right)$. The PCR process was stopped at $4^{\circ} \mathrm{C}$ (Ayuso-Sacido and Genilloud 2005). 


\subsection{Screening of $F A D H_{2}$-dependent halogenase gene}

PCR amplification of the $\mathrm{FADH}_{2}$-dependent halogenase gene was performed based on Hornung et al. (2007) method using set primers Halo-B4-FW (5'- TTCCCSCGSTACCASATCGGS GAG -3') and Halo-B7-RV (5'GSGGGATSWMCCAGWACCASC -3'). The final volume of reaction mixture of $25 \mu \mathrm{L}$ contained $12.5 \mu \mathrm{L}$ GoTaq ${ }^{\circledR}$ Green Master Mix, $1 \mu \mathrm{L}$ primer Halo-B4-FW (0.4 mM), $1 \mu \mathrm{L}$ primer Halo-B7-RV (0.4 mM), $1 \mu \mathrm{L}$ DNA Template, $1 \mu \mathrm{L}$ sterile DMSO, and 8,5 $\mu \mathrm{L}$ Nuclease Free-Water. The PCR program used was pre-denaturation (95 ${ }^{\circ} \mathrm{C}$ for $\left.3 \mathrm{~min}\right), 30$ cycles of denaturation $\left(94^{\circ} \mathrm{C}\right.$ for 1 min), annealing $\left(58^{\circ} \mathrm{C}\right.$ for $90 \mathrm{~s}$ ) and extension $\left(72^{\circ} \mathrm{C}\right.$ for $1 \mathrm{~min})$, and a final extension $\left(72^{\circ} \mathrm{C}\right.$ for $5 \mathrm{~min}$ ).

\subsection{UV visualization of $P C R$ products}

The PCR products were observed on agarose gels, containing $30 \mathrm{~mL}$ TAE $1 \mathrm{x}$ and $0.75 \mu \mathrm{L}$ RedSafe was added for electrophoresis staining then visualized on a UV transilluminator. This process was aimed to ensure that a fragment of the correct size had been amplified.

\subsection{Fermentation and extraction of metabolites}

Production of secondary metabolites of actinobacteria was assessed using 6 well plate. Actinobacteria were inoculated in various media and incubated at $28{ }^{\circ} \mathrm{C}$ for 6 days. The fermentation product was collected in falcon tube 15 $\mathrm{mL}$ and centrifuged to separate the supernatant. This supernatant was used for antibacterial assay. The media used for this fermentation were: M-1 consists of glucose $10 \mathrm{~g} / \mathrm{L}$, corn dextrin $40 \mathrm{~g} / \mathrm{L}$, sucrose $15 \mathrm{~g} / \mathrm{L}$, casein hydrolysate 10 $\mathrm{g} / \mathrm{L}, \mathrm{MgSO}_{4} .7 \mathrm{H}_{2} \mathrm{O} 1 \mathrm{~g} / \mathrm{L}$, and $\mathrm{CaCO}_{3} 2 \mathrm{~g} / \mathrm{L}$; M-5 containing sucrose $20 \mathrm{~g} / \mathrm{L}$, bacto peptone $2 \mathrm{~g} / \mathrm{L}$, cane molasses 5 $\mathrm{g} / \mathrm{L}, \mathrm{FeSO}_{4} .7 \mathrm{H}_{2} \mathrm{O} 0.1 \mathrm{~g} / \mathrm{L}, \mathrm{MgSO}_{4} .7 \mathrm{H}_{2} \mathrm{O} 0.2 \mathrm{~g} / \mathrm{L}$, potassium iodide $0.5 \mathrm{~g} / \mathrm{L}, \mathrm{CaCO}_{3} 5 \mathrm{~g} / \mathrm{L}$; M-15 consist of sucrose $340 \mathrm{~g} / \mathrm{L}$, glucose $10 \mathrm{~g} / \mathrm{L}$, bacto peptone $5 \mathrm{~g} / \mathrm{L}$, yeast extract $3 \mathrm{~g} / \mathrm{L}$, malt extract $3 \mathrm{~g} / \mathrm{L}$, and $\mathrm{MgCl}_{2} \cdot 6 \mathrm{H}_{2} \mathrm{O} 1 \mathrm{~g} / \mathrm{L} ; \mathrm{M}-23$ consists of glucose $1 \mathrm{~g} / \mathrm{L}$, soluble starch $24 \mathrm{~g} / \mathrm{L}$, bacto peptone $3 \mathrm{~g} / \mathrm{L}$, meat extract $3 \mathrm{~g} / \mathrm{L}$, yeast extract $5 \mathrm{~g} / \mathrm{L}, \mathrm{CaCO}_{3}$ $4 \mathrm{~g} / \mathrm{L}$; M-43 consists of glucose $20 \mathrm{~g} / \mathrm{L}$, lacto peptone 5 $\mathrm{g} / \mathrm{L}$, beef extract $5 \mathrm{~g} / \mathrm{L}, \mathrm{NaCl} 5 \mathrm{~g} / \mathrm{L}$, yeast extract $3 \mathrm{~g} / \mathrm{L}$, $\mathrm{CaCO}_{3} 5 \mathrm{~g} / \mathrm{L}$; and M-51 consist of sucrose $10 \mathrm{~g} / \mathrm{L}$, casein hydrolysate $8 \mathrm{~g} / \mathrm{L}$, yeast extract $4 \mathrm{~g} / \mathrm{L}, \mathrm{K}_{2} \mathrm{HPO}_{4} 3 \mathrm{~g} / \mathrm{L}$, $\mathrm{MgSO}_{4} .7 \mathrm{H}_{2} \mathrm{O} 0.3 \mathrm{~g} / \mathrm{L}$.

\subsection{Antibacterial bioassay of 96 well plate}

The antimicrobial activity of actinobacteria was assessed using 96 well plate. V. alginolyticus was used as test strain for antibacterial activity. V. alginolyticus was incubated in TSB saline media for $18 \mathrm{~h}$. A final concentration of $5 \times 10^{8}$ $\mathrm{cfu} / \mathrm{mL}$ was adopted for this assay. A volume of $20 \mu \mathrm{L}$ of fermentation product of actinobacteria, TSB saline media, and $V$. alginolyticus was pipetted into each well. The first row of the plate consist of positive control cyprofloxacin and amphicillin at a dose of $1 \mathrm{mg} / \mathrm{mL}$, TSB media and V. alginolyticus as negative control. The plate was incubated at $37^{\circ} \mathrm{C}$ for $16-20 \mathrm{~h}$. After incubation, $10 \mu \mathrm{L}$ resazurin was diluted as indicator then gently shake the plate. The color change was observed then assessed visually. Any color changes from purple to pink or colourless were recorded as negative bioactivity.

\subsection{Antibacterial overlay agar}

In this study, the antimicrobial activity also conducted using overlayed agar in 6 well plate. V. alginolyticus as test strain with the OD of 0.3 was inoculated in TSA media $\left(0.8 \%\right.$ agar) and incubated at $37^{\circ} \mathrm{C}$ for $16-18 \mathrm{~h}$. Total of 1 $\mathrm{mL}$ V. alginolyticus were overlayed on each plate of 7 days cultured actinobacteria and incubated for 16-18 h. After incubation, $25 \mathrm{~mL}$ resazurin was diluted as indicator then gently shake the plate until resazurin cover the entire surface. The color change was observed visually.

\subsection{Quick detection of peptide}

Peptide as representative compound of product NRPS gene was detected using on TLC plate and visualization by ninhydrin reagent. Ninhydrin reagent consist of $0.2 \mathrm{~g}$ ninhydrin in $100 \mathrm{~mL}$ ethanol (Zarzycki 2015). A total of $10 \mu \mathrm{L}$ product fermentation of actinobacteria was spotted on TLC plate and immersed in ninhydrin reagent. Plate of TLC was heated at $110^{\circ} \mathrm{C}$ and visually observed the appearance of spots. Peptide was characterized by the presence of pink, purple, until yellow spot on the TLC plate depends on variety aminoacids (Gibbons 2006).

\subsection{Sequencing and BLAST sequence analysis}

Product of PCR was cleaned using GenElute ${ }^{\mathrm{TM}}$ Gel Extraction Kit (Sigma-Aldrich). Product were sequenced by $1^{\text {st }}$ BASE Laboratories Malaysia services. Sequencing was performed using BigDye ${ }^{\circledR}$ Terminator v3.1 Cycle Sequencing Kit protocol. Technically sequencing performed using the same forward and reverse primer during PCR. DNA sequencing was carried out to determine the percent genotype similarity of isolates by $16 \mathrm{~S}$ rRNA and nrps gene. The sequences were compared to some available DNA sequences in GenBank (https://www.ncbi.nlm.nih.gov/genbank/). Sequences of nrps were translated using the Sequence Manipulation Suite (http://www.bioinformatics.org/sms2/) and compared to sequences within the NCBI protein database using BLASTp. Closely related 16S rRNA and nrps gene sequences were retrived from GenBank database to make phylogenetic trees. The phylogenetic trees were contructed using MEGA7 by neighbor-joining algorithm and a bootstrap consisting of 1,000 replications.

\section{Results}

\subsection{Isolation actinobacteria from Gelidiella acerosa}

A total of 15 actinobacteria were isolated from the red algae Gelidiella acerosa collected from Drini Gunungkidul Yogyakarta. Three isolates were grown in AIA media, 


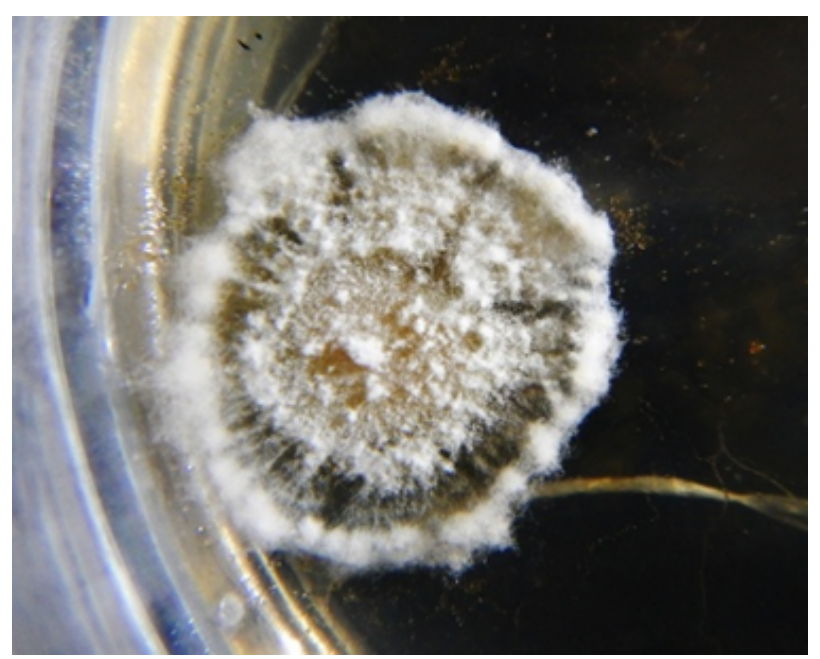

FIGURE 1 Morphology of one of the actinobacteria isolated from Gelidiella acerosa.

four isolates in SCSW media, three isolates in NB media, five isolates in MA media, and none of isolate grow in WAT-SW media.

Actinobacteria grow as branching hyphae on the agar surface, and mycelium form is prominent. Colonies grown on each media has a different morphology. Actinobacteria is able to producing brown, pink, gray, orange, purple, red, or white pigment (Holt 1994). Figure 1 showed an example one of isolate actinobacteria morphology white morphology spore-forming.

\subsection{Amplification of $16 S$ rRNA gene}

The 16S rRNA gene was amplified using special set primers for actinobacteria ActF/ActR (640bp) for amplifying the 16S rRNA gene in actinobacteria (Stach et al. 2003). Based on 16S rRNA actinobacteria gene amplification, 14 isolates confirmed as actinobacteria as presented in Figure 2.

\subsection{Screening of $F A D H_{2}$-dependent halogenase gene}

Genetic screening of $\mathrm{FADH}_{2}$-dependent halogenase gene was carried out using primers Halo-B4-FW and Halo-B7RV (Hornung et al. 2007). Figure 3 shows four isolates had 1000 bp as PCR product, while the correct size of $\mathrm{FADH}_{2}$-dependent halogenase gene targeted was $550 \mathrm{bp}$.

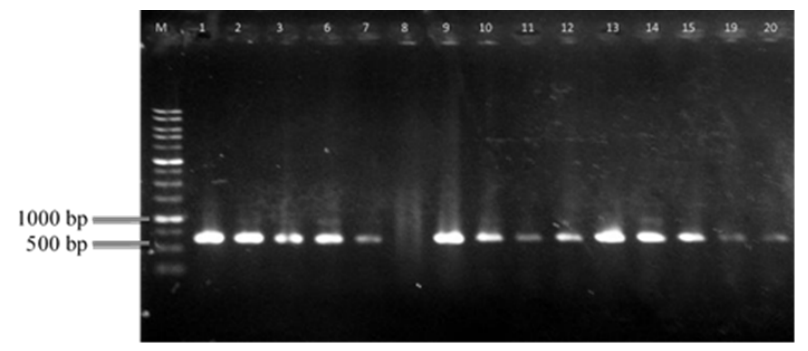

FIGURE 2 Visualization of $16 \mathrm{~S}$ rRNA gene representative selective amplification of 640 bp fragments using primers ActF/ActR in 1\% $(w / v)$ agarose gel stained with RedSafe.

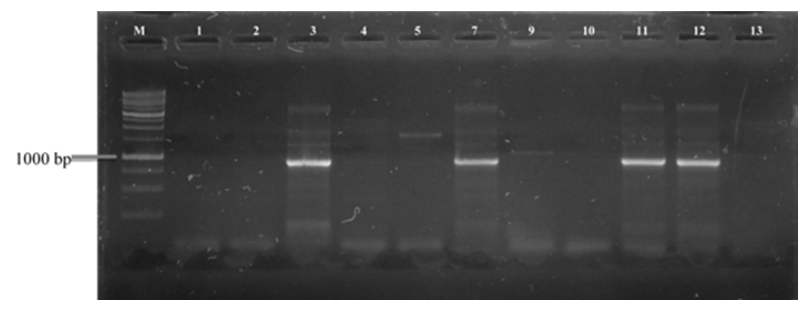

FIGURE 3 Visualization of FADH H $_{2}$-dependent halogenase gene representative selective amplification of 550 bp fragments using primers Halo-B4-FW and Halo-B7-RV in $1 \%(\mathrm{w} / \mathrm{v})$ agarose gel stained with RedSafe.

Based on BLAST analysis in NCBI database revealed the 1000 bp sequences has no similarity with any halogenase genes. This concludes that none of actinobacteria in this study contain $\mathrm{FADH}_{2}$-dependent halogenase.

\subsection{Screening of NRPS gene (non-ribosomal peptide synthase)}

Detection of NRPS gene was carried out using set primers A3F/A7R. All of the templates were amplified at 700bp $(100 \%)$ as represent in Figure 4. This results show presence of NRPS gene is dominant. Ayuso-Sacido and Genilloud (2005) screened 210 isolates of actinobacteria and obtained 167 have NRPS gene (79.5\%).

\subsection{Bioassay antivibrio}

Bioassay anti-vibrio was performed using 96 well plate diluted bioassay. This assay was adopted from Gibbons (2006) with slight modifications. Test material used for this assay was fermentation extract of actinobacteria. The changing color from purple to pink or colourless is due to metabolism of bacteria means that the metabolites were inactive. While the absence of color changing means that no bacterial metabolism because the compounds killed the bacteria (Figure 5). About eight of isolates actinobaceria showed inhibition against $V$. alginolyticus.

Bioassay antivibrio also performed in overlay agar using 6 well plate in 6 different media fermentation. Actinobacteria produced secondary metabolites intracellular within cells while extracellular secondary metabolites directly secreted out of the cell and diffused to media. It will determine the purple pattern on antibacterial bioassay. Intracellular secondary metabolites was showed on purple

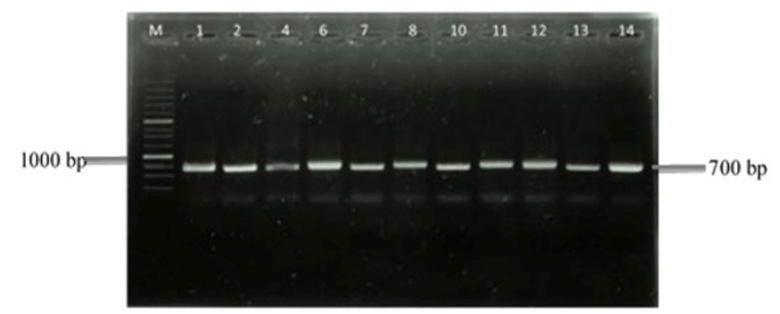

FIGURE 4 Visualization of NRPS gene representative selective amplification of $700 \mathrm{bp}$ fragments using primers A3F and A7R in 1\% $(\mathrm{w} / \mathrm{v})$ agarose gel stained with RedSafe. 


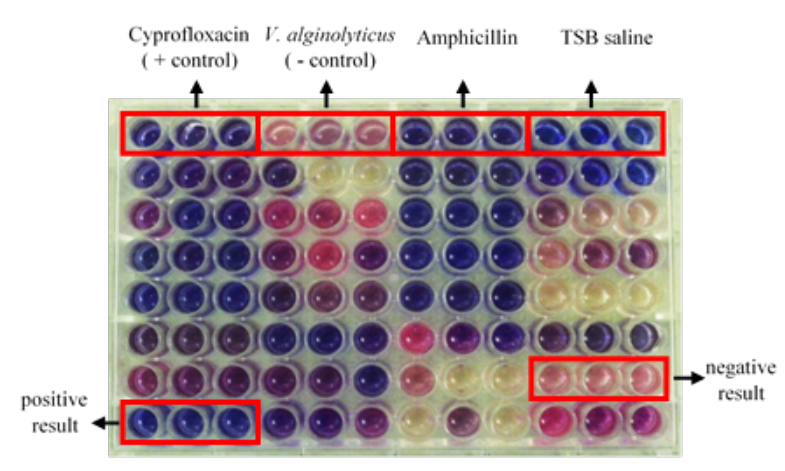

FIGURE 5 Antibacterial qualitative assay against Vibrio alginolyticus.

pattern at isolates grown area while the purple pattern of extracellular secondary metabolites was showed around media as represented in Figure 6.

\subsection{Quick detection of peptide}

Based on detection with the use of ninhydrin as respective visualizing agent showed a total 54 of 84 product fermentation of actinobacteria were contained peptide as a bioactive compound. The appearance of pink, purple, or yellow spot on plate showed the compound contained peptide with different aminoacid (Figure 7). The pink spot presented the presence of phenylalanine, the purple spot showed the presence of tryptophan, and the yellow spot showed the presence of proline (Gibbons 2006; Zarzycki 2015).

\section{Discussion}

NRPS are large multimodular enzymes involved in biosynthesis of peptide secondary metabolites produced by microorganisms, such as bacteria (Felnagle et al. 2008). Some of antibiotics such as vancomycin and teicoplanin have exquisitely complex structures catalysed by NRPS (Pace and Yang 2006). Indeed, almost all antibiotic peptide are catalysed by NRPS. The presence of nrps gene in isolates can be proved by molecular screening and the expression of this gene in producing peptide should be checked through chemical screening.

NRPS and $\mathrm{FADH}_{2}$-dependent halogenase are enzymes involved in the biosynthesis of important biological compounds produced by microorganism including acti-

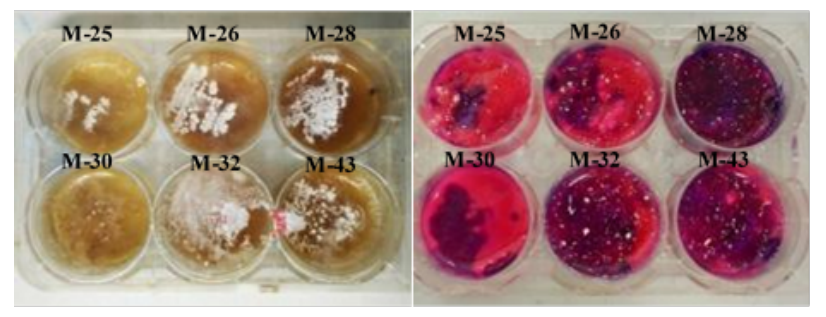

FIGURE 6 Results of bioassay antivibrio before (left) and after indicator (right).

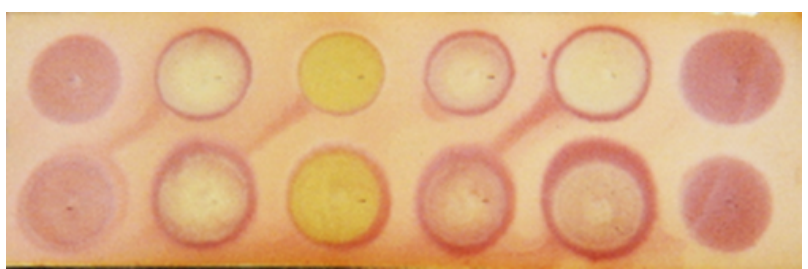

FIGURE 7 TLC visualization of secondary metabolites of actinobactera with ninhydrin reagent.

nobacteria. A band about 700 bp length was detected in 14 isolates by PCR screening of NRPS gene. The high detection levels of NRPS biosynthetic systems observed in our isolates confirmed the wide distribution of these sequences in this bacterial group. While detection of $\mathrm{FADH}_{2}$-dependent halogenase gene was obtained a band about 1000 bp length. Hornung et al. (2007) mentioned the precise length of this gene was about $550 \mathrm{bp}$. Analysis of this 1000 bp sequences in NCBI database confirmed this sequences has no similarity with any halogenase genes. In this research none of $\mathrm{FADH}_{2}$-dependent halogenase gene was detected. Existence of this gene as auxiliary gene of secondary metabolites biosynthesis is rare or even absent. The presence of $\mathrm{FADH}_{2}$-dependent halogenase gene in all observed isolates was only $4 \%$ compared with existence of NRPS and PKS gene as the backbone of biosynthetis secondary metabolites (Hur et al. 2012).

Bioactivity screening was conducted to the fermentation product of actinobacteria that active as antibacterial agent. Fermentation was asessed by growing actinobacteria in various media to creating diverse environmental conditions. One strain many compound (OSMAC) show one strain of bacteria can produce diverse compounds depending on environmental conditions (Bode et al. 2002). A variety compounds are produced during actinobacteria fermentation and due to the nutrient limitation for the defense mechanisms.

Resazurin is an oxidation-reduction indicator used for the evaluation of bacterial growth (McNicholl et al. 2007). It is a blue dye that becomes pink when reduced to resofurin by oxidoreductases Gram negative bacteria (Leonard et al. 2008). Resofurin is further reduced to hydroresofurin (uncolored). The absence of indicator change color indicate that the fermentation product of actinobacteria was able to inhibit the growth of $V$. alginolyticus. The change color become pink or colorless showed that the fermentation product of actinobacteria failure to inhibit the test strain and the cells of $V$. alginolyticus still remain on the well.

Identification of peptide is important to assure that nrps gene was expressed under certain condition. Chemical screening on TLC plate was an easy and rapid approach that require specific reagents to visualize the isolates capability to produce active secondary metabolites. Due to the existence of -NH-CO- groups in peptides, ninhydrin has greater ability to detect peptides. The reaction between 


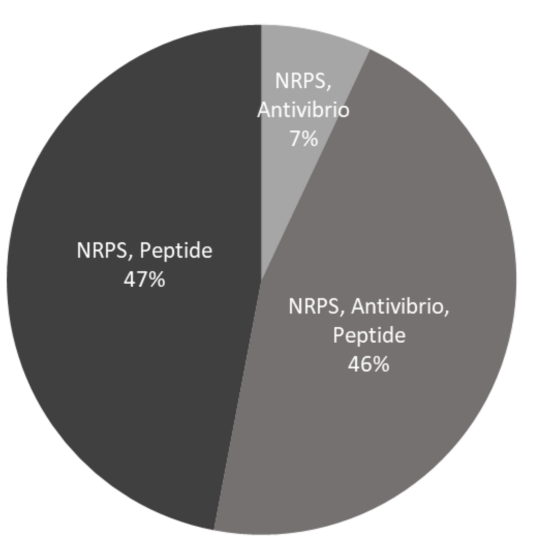

FIGURE 8 Chart of genetic, bioactivity, and peptide screening of actinobacteria associated red algae Gelidiella acerosa.

amino acids and ninhydrin produces reddish color as represented of most amino acids except proline and hydroxyproline produce yellow color. The result of chemical screening revealed that almost all isolates produced secondary metabolites containing peptide. The genetic, chemical, and bioactivity result of 14 isolates actinobacteria was showed in Figure 8. There are $47 \%$ isolates have nrps gene, produce peptide and active against $V$. alginolyticus, while the same number of isolates have nrps genes, produce peptide but inactive against $V$. alginolyticus. Only $6 \%$ isolates have nrps gene, no peptide but active against V. alginolyticus.

In this study, we identify one potential isolate of actinobacteria. Based on sequences analysis of $16 \mathrm{~S}$ rRNA gene sequences of isolates DR-2S-115-5 has similarity to Nocardiopsis alba PCM 2702 (97\%). Nocardiopsis species are able to prevail under different environmental conditions mainly because of their versatile genetic make-up, secretion of enzymes, production of compatible solutes and surfactants (Li et al. 2013; Bennur et al.

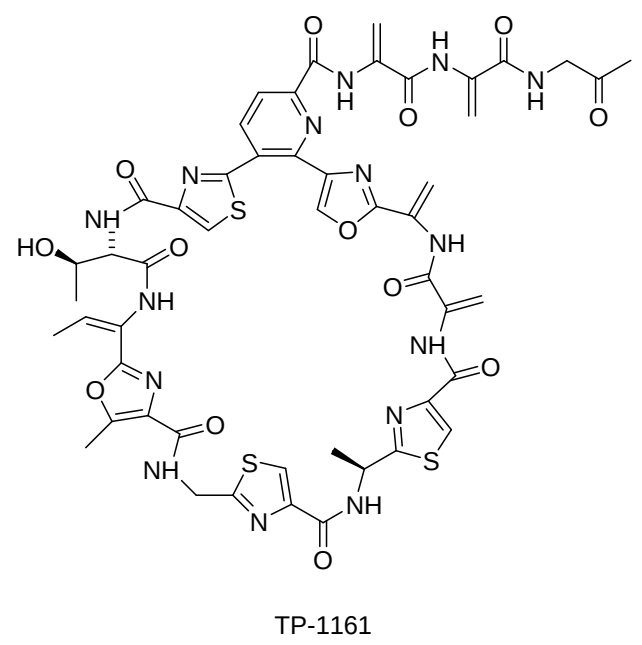

FIGURE 9 Chemical structure of macrocyclic thiopeptide antibiotics TP-1161 produced by Nocardiopsis.

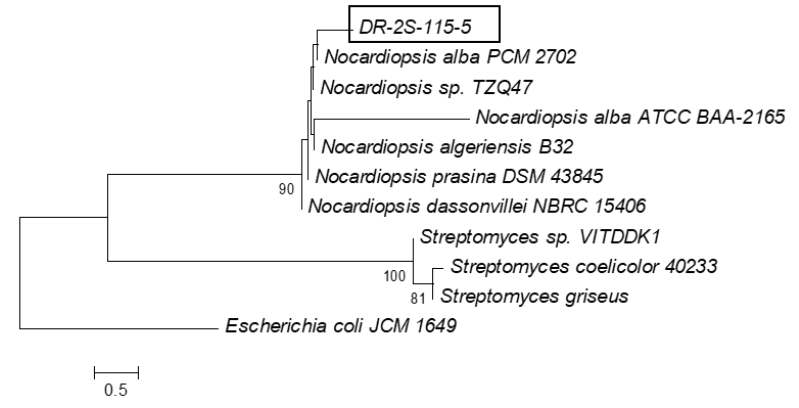

FIGURE 10 Phylogenetic tree of isolates DR-2S-115-5 based on $16 \mathrm{~S}$ rRNA gene sequence by neighbour joining method with $1000 \mathrm{x}$ bootsrap replication.

2014). In addition to these features, they produce an array of bioactive compounds that may help their survival under these conditions. Nocardiopsis has been isolated from marine sediments, marine invertebrates association, and hyper saline environments (He et al. 2015). Nocardiopsis produce bioactive compounds with various activities such as antibiotics, anticancer, and immunomodulator agent (Bennur et al. 2016). Macrocyclic thiopeptide antibiotics TP-1161 produced by marine Nocardiopsis sp. TFS65-07 isolated from sediments at a depth of $24 \mathrm{~m}$ collected in Trondheim Fjord, Norway. TP-1161 showed antibacterial activity against Gram-positive bacteria (Engelhardt et al. 2010). Peptidolipins, peptide antibiotics produced by Nocardia sp. WMMB 215 isolated from ascidian Trididemnum orbiclatum. These compounds showed bacteriostatic activity agaisnt MRSA and MSSA (methicillin sensitive Staphylococcus aureus) (Wyche et al. 2012).

Analysis of the NRPS sequences with registered protein in the NCBI database confirmed that the NRPS gene of isolate DR-2R-115-35 has similarity to the genus Streptomyces. This genus has commercial interest due to their unique capacity to produce novel metabolites. Total of $80 \%$ antibiotics have been discovered from Streptomyces (Naikpatil and Rathod 2011) included antibiotic on the market such as streptomycin, tetracycline, chlortetracycline, neomycin, spiramycin, and daptomycin. The presence of NRPS gene of isolate DR-2R-115-35 have a high

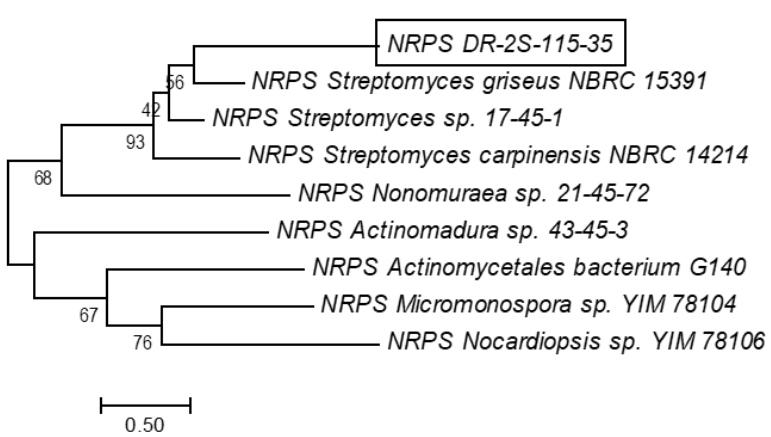

FIGURE 11 Phylogenetic tree of NRPS gene sequence isolates DR$2 \mathrm{~S}-115-35$ by neighbour joining method with 1000 x bootsrap replication. 
potential to produce antibiotic.

\section{Conclusions}

Our result revealed that actinobacteria associated red algae Gelidiella acerosa are potential as producer of antibacterial compound. Genetic based screening yielded that 14 actinobacteria contained $n r p s$ gene associated with marine peptide. The bioactivity assay showed that eight isolates of actinobacteria were active against $V$. alginolyticus. In conclusion, isolate actinobacteria are wealth sources of bioactive compounds.

\section{Acknowledgments}

The authors would like to thank Universitas Gadjah Mada for supporting our research under scheme Hibah Kompetensi (HIKOM) 2014: LPPM-UGM/1191/UT/2014, New Zealand Community Resilience and Economic Development (CaRED) Program and Grant Student Publication BPP UGM 2016: 955/BPP/2016 to Noer Kasanah. The authors are thankful to Research Group of Marine Biotechnology for the assistance.

\section{Authors' contributions}

MU carried out the laboratory work and wrote the manuscript. NK as the first adviser designed the study, wrote the manuscript, and reviewed the manuscript. NSNH reviewed the manuscript. All authors read and approved the final version of the manuscript.

\section{Competing interests}

Authors declare no conflict of interest related to this manuscript.

\section{References}

Austin B. 2010. Vibrios as causal agents of zoonoses. Vet Microbiol. 140(3-4):310-317. doi:10.1016/j.vetmic.2009.03.015.

Ayuso-Sacido A, Genilloud O. 2005. New PCR primers for the screening of NRPS and PKS-I systems in actinomycetes: detection and distribution of these biosynthetic gene sequences in major taxonomic groups. Microb Ecol. 49(1):10-24. doi:10.1007/s00248-0040249-6.

Bennur T, Kumar AR, Zinjarde S, Javdekar V. 2014. Nocardiopsis species as potential sources of diverse and novel extracellular enzymes. Appl Microbiol Biotechnol. 98(22):9173-9185. doi:10.1007/s00253014-6111-y.

Bennur T, Ravi Kumar A, Zinjarde S, Javdekar V. 2016. Nocardiopsis species: a potential source of bioactive compounds. J Appl Microbiol. 120(1):1-16. doi:10.1111/jam.12950.
Blunt JW, Copp BR, Keyzers RA, Munro MHG, Prinsep MR. 2014. Marine natural products. Nat Prod Rep. 31(2):160. doi:10.1039/c3np70117d.

Bode HB, Bethe B, Höfs R, Zeeck A. 2002. Big effects from small changes: possible ways to explore nature's chemical diversity. ChemBioChem 3(7):619-627. doi:10.1002/1439-7633(20020703)3:7<619::AIDCBIC619>3.0.CO;2-9.

Bull AT, Ward AC, Goodfellow M. 2000. Search and discovery strategies for biotechnology: the paradigm shift. Microbiol Mol Biol Rev. 64(3):573-606.

Egan S, Thomas T, Kjelleberg S. 2008. Unlocking the diversity and biotechnological potential of marine surface associated microbial communities. Curr Opin Microbiol. 11(3):219-225. doi:10.1016/j.mib.2008.04.001.

El-Shatoury SA, El-Shenawy NS, El-Salam IMA. 2009. Antimicrobial, antitumor and in vivo cytotoxicity of actinomycetes inhabiting marine shellfish. World J Microbiol Biotechnol. 25(9):1547-1555. doi:10.1007/s11274-009-0040-4.

Elsie BH, Dhanarajan MS, Sudha PN. 2011. Invitro screening of secondary metabolites and antimicrobial activities of ethanol and acetone extracts from red seaweed Gelidium acerosa. J Chem Res. 2(2):1-3.

Engelhardt K, Degnes KF, Zotchev SB. 2010. Isolation and characterization of the gene cluster for biosynthesis of the thiopeptide antibiotic TP1161. Appl Environ Microbiol. 76(21):7093-7101. doi:10.1128/AEM.01442-10.

Felnagle EA, Jackson EE, Chan YA, Podevels AM, Berti AD, McMahon MD, Thomas MG. 2008. Nonribosomal peptide synthetases involved in the production of medically relevant natural products. Mol Pharmaceutics 5(2):191-211. doi:10.1021/mp700137g.

Gibbons S. 2006. An introduction to planar chromatography. In: SD Sarker, Z Latif, AI Gray, editors. Methods in biotechnology-natural products isolation. Totowa, NJ: Humana Press. p. 77-116. doi:10.1385/1-59259955-9:77.

Gómez-León J, Villamil L, Lemos ML, Novoa B, Figueras A. 2005. Isolation of Vibrio alginolyticus and Vibrio splendidus from aquacultured carpet shell clam (Ruditapes decussatus) larvae associated with mass mortalities. Appl Environ Microbiol. 71(1):98-104. doi:10.1128/AEM.71.1.98-104.2005.

He ST, Zhi XY, Jiang H, Yang LL, Wu JY, Zhang YG, Hozzein WN, Li WJ. 2015. Biogeography of Nocardiopsis strains from hypersaline environments of Yunnan and Xinjiang Provinces, western China. Scientific Reports 5:13323. doi:10.1038/srep13323.

Holt JG. 1994. Bergey's manual of determinative bacteriology. Lippincott Williams \& Wilkins.

Hornung A, Bertazzo M, Dziarnowski A, Schneider K, Welzel K, Wohlert SE, Holzenkämpfer M, Nichol- 
son GJ, Bechthold A, Süssmuth RD, Vente A, Pelzer S. 2007. A genomic screening approach to the structure-guided identification of drug candidates from natural sources. ChemBioChem 8(7):757-766. doi:10.1002/cbic.200600375.

Hur GH, Vickery CR, Burkart MD. 2012. Explorations of catalytic domains in non-ribosomal peptide synthetase enzymology. Nat Prod Rep. 29(10):10741098. doi:10.1039/c2np20025b.

Kanagasabhapathy M, Sasaki H, Haldar S, Yamasaki S, Nagata S. 2006. Antibacterial activities of marine epibiotic bacteria isolated from brown algae of Japan. Ann Microbiol. 56(2):167-173.

Kasanah N, Hamann MT. 2004. Development of antibiotics and the future of marine microorganisms to stem the tide of antibiotic resistance. Curr Opin Investig Drugs 5(8):827-837.

Lam KS. 2006. Discovery of novel metabolites from marine actinomycetes. Curr Opin Microbiol. 9(3):245251. doi:10.1016/j.mib.2006.03.004.

Lee DW, Lee SD. 2008. Tessaracoccus flavescens sp. nov., isolated from marine sediment. Int J Syst Evol Microbiol. 58(4):785-789. doi:10.1099/ijs.0.64868-0.

Lee SD. 2006. Phycicoccus jejuensis gen. nov., sp. nov., an actinomycete isolated from seaweed. Int J Syst Evol Microbiol. 56(10):2369-2373. doi:10.1099/ijs.0.64271-0.

Leonard B, Coronel J, Siedner M, Grandjean L, Caviedes L, Navarro P, Gilman RH, Moore DAJ. 2008. Interand intra-assay reproducibility of microplate alamar blue assay results for isoniazid, rifampicin, ethambutol, streptomycin, ciprofloxacin, and capreomycin drug susceptibility testing of Mycobacterium tuberculosis. J Clin Microbiol. 46(10):3526-3529. doi:10.1128/JCM.02083-07.

Li HW, Zhi XY, Yao JC, Zhou Y, Tang SK, Klenk HP, Zhao J, Li WJ. 2013. Comparative genomic analysis of the genus Nocardiopsis provides new insights into its genetic mechanisms of environmental adaptability. PLOS ONE 8(4):e61528. doi:10.1371/journal.pone.0061528.

Luyt CE, Bréchot N, Trouillet JL, Chastre J. 2014. Antibiotic stewardship in the intensive care unit. Crit Care 18(5):480. doi:10.1186/s13054-014-0480-6.

Matsuo Y, Kanoh K, Jang JH, Adachi K, Matsuda S, Miki O, Kato T, Shizuri Y. 2011. Streptobactin, a tricatechol-type siderophore from marine-derived Streptomyces sp. YM5-799. J Nat Prod. 74(11):23712376. doi:10.1021/np200290j.

McNicholl BP, McGrath JW, Quinn JP. 2007. Development and application of a resazurinbased biomass activity test for activated sludge plant management. Water Res. 41(1):127-133. doi:10.1016/j.watres.2006.10.002.

Mustapha S, Mustapha EM, Nozha C. 2013. Vibrio al- ginolyticus: an emerging pathogen of foodborne diseases. Int J Sci Technol. 2:302-309.

Naikpatil SV, Rathod JL. 2011. Selective isolation and antimicrobial activity of rare actinomycetes from mangrove sediment of Karwar. J Ecobiotechnol. 3(10):4853.

Pace JL, Yang G. 2006. Glycopeptides: Update on an old successful antibiotic class. Biochem Pharmacol. 71(7):968-980. doi:10.1016/j.bcp.2005.12.005.

Penesyan A, Kjelleberg S, Egan S. 2010. Development of novel drugs from marine surface associated microorganisms. Mar Drugs 8(3):438-459. doi:10.3390/md8030438.

Piel J, Hui D, Wen G, Butzke D, Platzer M, Fusetani N, Matsunaga S. 2004. Antitumor polyketide biosynthesis by an uncultivated bacterial symbiont of the marine sponge Theonella swinhoei. Proc Natl Acad Sci USA 101(46):16222-16227. doi:10.1073/pnas.0405976101.

Pée KHv, Zehner S. 2003. Enzymology and molecular genetics of biological halogenation. In: Natural production of organohalogen compounds. The handbook of environmental chemistry. Berlin: Springer. p. 171199. doi:10.1007/b10457.

Schwartsmann G, Brondani da Rocha A, Berlinck RG, Jimeno J. 2001. Marine organisms as a source of new anticancer agents. Lancet Oncol. 2(4):221-225. doi:10.1016/s1470-2045(00)00292-8.

Schwarzer D, Marahiel MA. 2001. Multimodular biocatalysts for natural product assembly. Naturwissenschaften 88(3):93-101. doi:10.1007/s001140100211.

Shaw KS, Goldstein RER, He X, Jacobs JM, Crump BC, Sapkota AR. 2014. Antimicrobial susceptibility of Vibrio vulnificus and Vibrio parahaemolyticus recovered from recreational and commercial areas of Chesapeake Bay and Maryland Coastal Bays. PLOS ONE 9(2):e89616. doi:10.1371/journal.pone.0089616.

Singh RP, Reddy CRK. 2014. Seaweed-microbial interactions: key functions of seaweed-associated bacteria. FEMS Microbiol Ecol. 88(2):213-230. doi:10.1111/1574-6941.12297.

Soria-Mercado IE, Villarreal-Gómez LJ, Rivas GG, Sánchez NEA. 2012. Bioactive compounds from bacteria associated to marine algae. In: R Sammour, editor. Biotechnology - molecular studies and novel applications for improved quality of human life. InTech. doi:10.5772/27842.

Stach JEM, Maldonado LA, Ward AC, Goodfellow M, Bull AT. 2003. New primers for the class Actinobacteria: application to marine and terrestrial environments. Environ Microbiol. 5(10):828-841. doi:10.1046/j.1462-2920.2003.00483.x.

Wyche TP, Hou Y, Vazquez-Rivera E, Braun D, Bugni TS. 2012. Peptidolipins B-F, antibacterial lipopeptides 
from an ascidian-derived Nocardia sp. J Nat Prod. 75(4):735-740. doi:10.1021/np300016r.

Zarzycki PK. 2015. Chapter 8-Staining and derivatization techniques for visualization in planar chromatography. In: CF Poole, editor. Instrumental thinlayer chromatography. Boston: Elsevier. p. 191-237. doi:10.1016/B978-0-12-417223-4.00008-X. 